\title{
Germany's Investment in the Renewable Energy
}

\author{
Hafidh J. Arab ${ }^{1}$ and Aran B. Taha² \\ ${ }^{1}$ Department of Economics, Administration and Economics College, Nawroz University, \\ Duhok, Kurdistan Region - F.R. Iraq \\ ${ }^{2}$ Department of Economics, Research Center (SRD), Nawroz University, \\ Duhok, Kurdistan Region - F.R. Iraq
}

\begin{abstract}
Germany is one of the pioneer countries in the field of using all kinds of renewable energy. This inclination has come as an outcome of the environment pollution, because of the hyper - use of the traditional kinds of energy (coal, petrol, and gas), and let alone the other effects of increase in temperature and climate change. Hence, the heading to use renewable kinds of energy has become a demand of the global community. This study concluded that Germany, in particular, has been expanding the production of the renewable kinds of energy; meanwhile, it is decreasing its dependence on the traditional kinds of energy. This, doubtlessly, has been achieved through big deals of investments in the field of renewable energy projects, in all kinds of the said energy, whether solar power, or hydropower, or wind power, or even geothermal power, etc. Therefore, Germany aims at depending more and more on environmentally friendly resources of energy, to decrease the effects of climate change and pollution, which both have made dangerous threats to our plant. Hence, it might not be surprising the spreading - out of the renewable - energy projects, and not to mention the decreasing of their costs via scientific research and technological development, and their costs are competitively becoming even less than the costs of the traditional energy resources. Finally, Germany is also aiming at complete transference to the environmentally - friendly resources of energy, to mitigate, if not to stop completely, the environmental deterioration, as one of the German goals for the new millennium.
\end{abstract}

KEY WORDS: Renewable Energy, Green Investment, Environment, Solar Energy, Wind Energy, Hydro Energy

\section{INTRODUCTION}

Renewable energy is defined as energy that is collected from resources which are naturally replenished, such as solar, wind, rain, tidal waves, and geothermal heat (Ellaban, et al., 2014. p. 748). Renewable energy often generates energy in four important areas: Electricity generation, air and water heating/cooling, transportation, and rural (off-grid) energy services based on REN21's (2014) report, renewables contributed $19 \%$ to worldwide energy consumption and $22 \%$ to their generation of electricity in 2012 and 2013, respectively. This energy consumption is divided as $9 \%$

Academic Journal of Nawroz University (AJNU)

Volume 6, No 3(2017), 5 pages

Received 22 April 2017; Accepted 01 June 2017

Regular research paper: Published 18 July 2017

Corresponding author's e-mail: arantaha@nawroz.edu.krd / dr.hafidh_almoula@nawroz.edu.krd

Copyright @2017 Hafidh Jasim Arab, Aran Baderkhan Taha. This is an open access article distributed under the Creative Commons Attribution License. coming from traditional biomass, $4.2 \%$ as heat energy (non-biomass), $3.8 \%$ hydroelectricity, and $2 \%$ is electricity from wind, solar, geothermal, and biomass. Worldwide investments in renewable technologies amounted to more than US\$ 214 billion in 2013, with countries such as China and the United States heavily investing in wind, hydro, solar, and biofuels (Lins, 2014). The report described that,

Projected levels of renewable energy for 2020 were already surpassed by 2010 .

1. Global installed capacity and production from all renewable technologies have increased substantially

2. Significant cost reductions for most technologies supporting policies spread throughout the world.

Renewable energy resources exist over wide geographical areas, in contrast to other energy sources, which are concentrated in a limited number of countries. Rapid deployment of renewable energy and energy efficiency is resulting in significant energy security, climate change mitigation, and economic benefits. The results of a recent review of the literature concluded that as greenhouse gas (GHG) emitters begin to be held liable for damages 
resulting from (GHG) emissions resulting in climate change, a high value for liability mitigation would provide powerful incentives for deployment of renewable energy technologies. In international public opinion surveys, there is strong support for promoting renewable sources such as solar power and wind power. At the national level, at least 30 nations worldwide already have renewable energy contributing more than $20 \%$ of energy supply. National renewable energy markets are projected to continue to grow strongly in the coming decade and beyond (REN, 2013). Some places and at least two countries, Iceland and Norway, generate all their electricity using renewable energy already, and many other countries have the set a goal to reach $(100 \%)$.

\subsection{Germany's Renewable Energy Sector Introduction}

Germany's most beautiful location, for instance, is the raging North Sea. Germany's first offshore wind farm, titled as Alpha Ventus and installed $45 \mathrm{~km}$ off the coast, generates electricity for 70,000 households. Tourists can get a close view by sea or on a scenic flight. In the center of Berlin: Commercial buildings, offices and convention centers are air-conditioned with hot water by using sophisticated technology. Hikers climbing up to the pumped storage power plant at Wehr in Hotzenwald; conservation of energy in the form of water in an artificial lake, looks like a huge battery. Samuel Johnson author of "the use of traveling" once said "is to regulate imagination by reality, and instead of thinking how things may be, to see them as they are." Leave the tourism and picnics behind, and if you have a prejudice against radical ideas on eco-friendly energy, at least take a look at how strongly Germans progress in producing green energy and what they achieved in the way of green economy. The definition of renewable energy is the energy from a source that is not depleted when used such as wind or solar power. Any naturally occurring theoretically inexhaustible source of energy, as biomass, solar, wind, tidal, wave, and hydroelectric power that is not derived from fossil or nuclear fuel. Assay will discuss renewable energy in general, as well as geothermal, solar, wind, biofuel and hydroelectricity in general and specifically related with Germany. As of 2013Germany, Japan and China, three largest economies of world, as well as India, generate electricity from renewable sources more than from nuclear power. Based on REN21's report (Secretariat, 2014), renewable contributed $19 \%$ to world's energy consumption. This energy consumption is separated as $9 \%$ from usual biomass, $4.2 \%$ as heat energy (non-biomass), $3.8 \%$ hydroelectricity, and $2 \%$ is electricity from wind, solar, geothermal, and biomass.

To capture climate change, an evolution to a low-carbon economy must take place speedily (Jacobson and Lauder, 2006). Thus, the rate of transmission to new technologies, such as those for the production of electrical energy from renewable energy sources becomes a core issue. This article is to dig in the investments made by Germany in renewable energy sources such as wind turbines, solar cells, biogas, and tidal energy. Germany is among the ground - breaking and thriving worldwide. Net - generation from renewable energy sources electricity sector has greater than before $6.3 \%$ in 2000 to $30 \%$ in 2014 (Burger, 2014). Wind, solar and biogas, collectively accounted for a raising share of net electricity generation than coal in the first 6 months of year 2014 (Business Spectator, July 2014). While the highest production from both solar and wind reached a new height of all - times, i.e., 74\% in April (2014) (Kroh, 2014). The wind power alone in December 12, 2014, reached to $562 \mathrm{GWh}$. Germany was well deserved for the title "the world's first major renewable energy economy" (Burgermeister, 2009). Around 23,550 wind turbines and 1.95 million solar photovoltaic (PV) systems are distributed all over the country's area of $357,000 \mathrm{~km}^{2}$ (Wirth and Schneider, 2013). Germany's central government is working commercialization plan for renewable energy with a specific focus on offshore wind farms. The development of adequate network capacities to transmit the power generated in the North Sea to the large industrial estates in the Southern parts is a challenge for the think tanks of Germany. The sector wise investments in renewable energy sector Germany will be discussed onward.

\section{ENERGY CONSUMPTION IN GERMANY}

Germany's primary energy consumption of 1,449 Pet joules or 403 TWh refers to the total energy used by the nation. The final energy consumption, split by the sectors, and with their relative share, are the so called "Erneuerbare Energien" (Renewable Energy) in Germany, February 2014.

- Electricity sector, with a gross - consumption of $49 \%$ (161 TWh)

- Heating sector, with a final consumption of $40 \%$ (131 TWh)

- Transportation sector, consuming 11\% (35 TWh).

As of the end of 2014, renewable energy sources, such as biomass, biogas, biofuels, hydro, wind and solar, accounted for $11.1 \%$ of the country's primary energy consumption, a more than doubling compared to 2004, when renewables only contributed $4.5 \%$. Renewable contributes most to the electricity sector with $27.8 \%$ (gross-generation), followed by the heat and transportation sector with $9.9 \%$ and $5.4 \%$, respectively.

Although the terms "energy" and "electricity" are often used interchangeably, they should not be confused with one another, as electricity is only one form of energy and does not account for the energy consumed by combustion engines and heat boilers, used in transportation by vehicles and for the heating of buildings.

\section{BIOMASS}

While going for the global application of climate change policy and in preparation for the Paris Climate Change Conference (2015), Germany and other European countries 
undertakes vigorous policy which is going to minimize the rate of GHG emissions and give more rigorous exploitation of renewable energy sources for temperature control and electricity production, which posed reduced threats for the climate. The major provider of biomass in Germany is agriculture sector. Moreover, wood production contributes to $25 \%$ for biomass feedstock. The German Government-owned Research Centre for Forestry and Forest Products claims that there are also reserves which will be used to enhance biomass production. Agriculture is the most important source of ingredient used in the production of biodiesel and making substrates for the production of biogas. Biomass contributed 30\% of renewable electricity production and for $70 \%$ of all renewable energy which comes mostly from wood. The investment made by Germany in biomass sector is given in Table 1.

Germany truly showed the fulfillment of its commitment to blend $6.25 \%$ biofuels in petroleum by 2014 with the Biofuels Quota Act. Continuous rise in investment in the biomass and biofuel sector helped a lot in continuous growth of this section of renewable energy.

\section{HYDROELECTRICITY}

Hydroelectricity is the term referring to electricity generated by hydropower; the production of electrical power through the use of the gravitational force of falling or flowing water. It is the most widely used form of renewable energy, accounting for $16 \%$ of global electricity generation -3.427 TWh of electricity production in 2010 and is expected to increase about $3.1 \%$ each year for the next 25 years (Lehrer and Vassal, 2005. p. 839-855). In Germany, there is virtually no room for the construction of further hydroelectric power facilities. Almost all German rivers have been dammed and have been for quite some time. However, outside Germany's borders, there is still room for improvement. The total installed hydroelectric facility in Germany at the end of 2006 was 4.7 GW. Hydropower meets $3.5 \%$ of the electricity demand.

\section{WIND POWER}

The past 10 years have been the decade of wind power. At the end of 1999, wind turbines generated 2,875 MW. By the end of 2008, that number had skyrocketed to 23,903 . Wind is everywhere. Temperature differences in our atmosphere set gigantic masses of air in motion and the energy involved

TABLE 1

Green Investment in Germany for Period (2005-2014)

\begin{tabular}{lcccc}
\hline \hline Year & 2005 & 2012 & 2013 & 2014 \\
\hline Investment (Billion Euros) & 1.1 & 3.3 & 2.9 & 2.4 \\
\hline \hline
\end{tabular}

Agency, R.E. (2015). Fact - Sheet Renewables in Germany. Berlin.

p8. Available from: http:/ / www.unendlich-viel-energie.de/ english. [Last retrieved on 2016 Apr 28] in those shifts can easily be captured with the help of rotor blades. Using the principle of electromagnetic induction, a generator can transform the circular motion of those rotors into electricity. Germany now gets more of its energy from wind power than from hydro - electric sources. Last year, wind power supplied Germany with 7\% of its electricity. In states like Saxony - Unhalt, Schleswig - Holstein and Mecklenburg - Western Pomerania, wind power's share was well over $30 \%$. "State subsidies have really worked when it comes to wind power," Hubertus Bard, an expert with the German Economic Institute in Cologne. Wind power is relatively cheap. The EEG mandates that energy companies buy wind power for 9 cents per kWh - not much more than the price for conventional power on the electricity markets. "Wind power is the most economical of the renewable energies," says Bard. However, the market is not immune. Higher steel prices have meant that the EEG has had to be altered to increase the amount paid for each kilowatt - hour of wind energy. German official Bandit said in a statement that the fall in prices we have seen during the past decade has been unfortunately reversed (Wilkes, et al., 2012). Experts believe that the wind energy branch is going to grow dramatically in the future primarily offshore. Offshore wind parks have the dual advantage that they take advantage of stronger sea winds and are not as disruptive as they are on land. Offshore wind parks are generally several kilometers off the coast. The gigantic facilities are anchored to the sea floor, with large parks containing up to 100 generators. A high-tension cable can efficiently deliver the energy generated over long distances. The German government foresees a capacity of 20,000 to 30,000 MW from wind parks in the North and Baltic Seas by 2030. Such an output would represent the equivalent of 20-30 nuclear power plants, assuming an optimal wind supply. The first of those parks, known as Alpha Vent's, located $45 \mathrm{~km}$ off the coast near Bunkum, has recently gone online. Its 12 wind turbines produce $60 \mathrm{MW}$ enough to power 50,000 households (Foley, et al., 2012. p. 1-8). On land, things do not look nearly as rosy. In Germany, those areas with sufficient wind have already been built up. In addition, numerous citizens' groups have ramped up their protests to wind parks in recent years. One potential solution to this problem is known as "re-powering" a term meaning little more than re-equipping existing onshore wind parks with newer, more efficient turbines. The German Wind Energy Association thinks that re-powering has a huge potential and predicts that by 2020, a quarter of German electricity needs will be met with wind power.

\section{SOLAR ENERGY POTENTIAL OF GERMANY}

Solar power has huge potential. The sun, after all, is free, and there are plenty of roofs to put panels on. The problem is the costs. The facilities already installed will require an additional $€ 27$ billion for maintenance, and each year, new panels are installed (Palls, 2013). There is plenty of 
silicon available, the resource necessary in the production of solar panels, but production is difficult. That means depending on the type of panel and the amount of sun in the region where it is installed, it takes between 4 and 9 years before it produces as much energy as was used in making it. Subsidies, on the other hand, mean that the facilities have generally paid for themselves after just 4 years. The life span of a solar cell is between 30 and 40 years. The situation, of course, would be dramatically improved if the solar modules could be produced more cheaply. Moreover, recent years have shown that the process is underway. Just last year, prices fell by $25 \%$, a trend driven primarily by Chinese manufacturers. Should solar power 1 day become as cheap as conventional electricity, it would be nothing short of a revolution. Consumers would no longer have any reason not to buy solar panels and demand would explode meaning that solar power would begin to play a substantial role on the energy market. However, most experts believe that it will be decades before such a process takes hold. German environmentalists and Euro solar have succeeded in obtaining the government support for the 100,000 roofs program. In July 2012, a cumulative installed total solar PV power of $29.7 \mathrm{GW}$ was in place (Palls, 2013). Solar PV provided 18 TWh in 2011, 3\% of the total electricity demand. As solar power installations rise quickly, in the first half of 2012, about $5.3 \%$ of the total electricity demand was covered by solar power. Solar power broke a new record high, feeding 22 GW into the power grid, or as much as 20 nuclear power stations (Kroh, 2014).

\section{GEOTHERMAL ENERGY}

In theory, the potential is endless. However, the problem is the costs. As long as the drilling technology remains as expensive as it is today, geothermal will not play a major role in Germany's energy mix. In addition, geothermal drillings are risky. They can occasionally cause minor earthquakes and should the ground settle, nearby buildings are endangered. In the Southern German town of Stauffer, for example, the effects can be seen, with numerous buildings having cracked in recent years following geothermal drillings. In Wiesbaden, by contrast, water flowed out of the ground for days as a result of another geothermal project. Geothermal power in Germany is expected to grow, mainly because of a law that benefits the production of geothermal electricity and guarantees a feed - in tariff. However, after a renewable energy law that introduced a tariff scheme of $€ 0.15$ (US\$0.23) per $\mathrm{kWh}$ for electricity produced from geothermal sources came into effect that year, a construction boom was sparked and the new power plants are now starting to come online (Foley, et al., 2012).

\section{EMPLOYMENT OPPORTUNITIES IN RENEWABLE ENERGY SECTOR}

According to official figures, some 370,000 people were employed in the renewable energy sector in 2010, especially in small and medium-sized companies. This is an increase of around $8 \%$ compared to 2009 (around 339,500 jobs), and well over twice the number of jobs in $2004(160,500)$. About two-thirds of these jobs are attributed to the Renewable Energy Sources Act (Lehr, et al., 2008). Latest estimates show, in Germany in 2007, about 9, 400 people were employed in the hydropower sector which generated a total turnover of $€ 1.23$ billion.

\section{ECONOMIC BENEFITS OF RENEWABLE ENERGY - AN INVESTMENT HUB}

The German economy profits from the advent and rise of renewable energies. Investment in new installations of renewable energy plants increased to 18.8 billion Euro in 2014. Turnover from operating renewable energy plants amounted to 14.1 billion Euro in 2014. Investment in new renewable energy installations according to sector since the year 2000 (Table 2).

\section{RENEWABLES - A CRADLE OF INNOVATION}

The rise of renewable energies fosters innovation. New patents are indicative of this development. The number of patents for renewables in Germany has steeply increased. In 2013, their number plateaued on a high level. Number of patent applications in the area of renewable energies registered at the German Patent and Trade Mark Office (Table 3).

TABLE 2

Investment in New Renewable Energy Installations According to Sector Since the year 2000

\begin{tabular}{|c|c|c|c|c|c|}
\hline Year & 2000 & 2005 & 2012 & 2013 & 2014 \\
\hline Wind energy & 1.9 bn. Euro & 2.5 bn. Euro & 3.9 bn. Euro & 6.6 bn. Euro & 12.3 bn. Euro \\
\hline Biomass & $1.1 \mathrm{bn}$. Euro & 3.3 bn. Euro & 2.9 bn. Euro & $2.6 \mathrm{bn}$. Euro & $2.4 \mathrm{bn}$. Euro \\
\hline Geothermal and environmental heat & 0.1 bn. Euro & 0.3 bn. Euro & 1.1 bn. Euro & 1.1 bn. Euro & 1.0 bn. Euro \\
\hline Total & 4.6 bn. Euro & 11.9 bn. Euro & 20.3 bn. Euro & 15.7 bn. Euro & 18.8 bn. Euro \\
\hline
\end{tabular}

Agency, R.E. (2015). Fact - Sheet Renewables in Germany. Berlin. p8. Available from: http:/ /www.unendlich-viel-energie.de/english. [Last retrieved on 2016 Apr 28]. PV: Photovoltaic

Original article | doi: 10.25007/ajnu.v6n3a73 
TABLE 3

Number of Patent Applications in the Area of Renewable Energies Registered at the German Patent and Trade Mark Office

\begin{tabular}{lccccc}
\hline \hline Year & 2005 & 2010 & 2011 & 2012 & 2013 \\
\hline Solar & 165 & 775 & 975 & 1.033 & 918 \\
Wind & 164 & 575 & 726 & 915 & 796 \\
Hydro, tidal & 26 & 97 & 139 & 106 & 106 \\
Biogas, geothermal, others & 44 & 116 & 164 & 152 & 132 \\
Total & 399 & 1.563 & 2.004 & 2.206 & 1.952 \\
\hline \hline
\end{tabular}

Agency, R.E. (2015). Fact - Sheet Renewables in Germany. Berlin. p8. Available from: http://www.unendlich-viel-energie.de/ english. [Last retrieved on 2016 Apr 28]

\section{CONCLUSION}

Over the first two decades, the German energy transition focused on growth and market access. Producing additional kilowatt - hours was the driver for achieving leverage. Renewable energy technologies became more efficient over time, costs and prices decreased. This led to higher affordability for investors and a lightening burden for the public. The approach has been a decentralized one, involving many social groups in the expansion of renewables. This in turn resulted in high acceptance levels and in many citizens' financial participation. The existing infrastructure was strong enough to integrate increasing capacities. Backed by a propitious political environment, growth of renewables has been most dynamic in the power sector. In 2014, renewables surpassed lignite as Germany's most important energy source on the power market. Wind power traditionally claims the biggest renewables share on the power market. In 2014, PV contributed the biggest relative on year increase in terms of market share. The successful rise of renewables has so far been largely confined to the power sector. The heat and transport sectors have lagged behind. Technologies for expanding renewables in the heating and transport sectors are available. This decade, growth of renewables in Germany has so far been largely confined to the power sector. Apart from prospects for further growth in the power sector, there is huge untapped potential to expand the use of renewables energies in the heat and transport sectors too.

\section{RECOMMENDATIONS}

Germany is now shaping the next era of the energy transition. Lessons have been learned, while new challenges lie ahead. Apart from supplying energy, renewables will have to deliver capacity to support security of supply. For example, many more biogas power plants shall become more flexible. Demand side management is another factor in the context of leveling out fluctuations of solar and wind power. The grid will become more intelligent, deploying the most efficient technological solutions for connecting even higher shares of renewable energy. All stakeholders should be invited to invest, to install and to connect according to their specific needs and abilities. This could go along with a change of their business models. But most important, the energy transition has to become a holistic concept, integrating the benefits and needs of the heat and mobility sectors. The government should attract investors to investment in the transport and automobile sector.

\section{REFERENCES}

Agency, R.E. (2015). Fact - Sheet Renewables in Germany. Berlin. Available from: http://www.unendlich-viel-energie.de/english. [Last retrieved on 2016 Apr 28].

Burger, B. (2014). Electricity Production from Solar and Wind in Germany in 2012. Freiburg, Germany: Fraunhofer Institute for Solar Energy Systems.

Burgermeister, J. (2009). Germany: The World's First Major Renewable Energy Economy. Berlin: Renewable Energy World.

Ellaban, O. Abu-Rub, H \& Bleiberg, F. (2014). Renewable energy resources current status, future prospects and their enabling technology. Renewable and Sustainable Energy Reviews, 39, 748-764.

Federal Ministry for Economic Affairs and Energy. Historic Data about the Development of Renewable Energies in Germany Erneuerbare Energien (In German). February; 2014.

Foley, A.M., Leahy, P.G., Marvglia, A \& McVeigh, E.J. (2012). Current methods and advances in forecasting of wind power generation. Renewable Energy, 37(1), 1-8.

Jacobson, S \& Lauder, V. (2006). The politics and policy of energy system transformation - Explaining the German diffusion of renewable energy technology. Energy Policy, 34(3), 256-276.

Kroh, K. (2014), Solar Roadways Marketing Plan, Germany Sets New Record, Generating 74 Percent of Power Needs From Renewable Energy. Think Progress RSS. p13.

Lehr, U., Kitsch, J., Karzai, M., Lutz, C \& Elder, D. (2008). Renewable energy and employment in Germany. Energy Policy, 36(1), 108-117.

Lehrer, B., Czisch, G \& Vassolo, S. (2005). The impact of global change on the hydropower potential of Europe: A model - Based analysis. Energy Policy, 33(7), 839-855.

Lins, C. (2014). Renewables 2014 Global Status Report.

Palls, W., editor. (2013). Solar Power for the World: What You Wanted to Know About Photovoltaic. Vol. 4. Boca Raton: CRC Press.

REN. (2013), Global Status Report. p43-45.

Secretariat, R. (2014). Renewables 2014 Global Status Report. REN21, Paris.

Wilkes, J., Marcia, J \& Dragan, M. (2012). Wind in Power: 2011 European Statistics. Brussels: EWEA.

Wirth, H \& Schneider, K. (2013). Recent Facts about Photovoltaic in Germany. Germany: Report from Fraunhofer Institute for Solar Energy Systems. 